Rev. Int. Contam. Ambie. 35 (1) 237-246, 2019

DOI: 10.20937/RICA.2019.35.01.17

\title{
CHARACTERIZATION OF PULP AND PAPER MILL WASTE FOR THE PRODUCTION OF WASTE-BASED CEMENT
}

\author{
Lisandro SIMÃO ${ }^{1 *}$, Dachamir HOTZA ${ }^{2}$, Fabiano RAUPP-PEREIRA ${ }^{1,4}$, \\ João A. LABRINCHA ${ }^{3}$ and Oscar R.K. MONTEDO ${ }^{4}$
}

${ }^{1}$ Graduate Program in Materials Science and Engineering (PGMAT), Department of Mechanical Engineering (EMC), Federal University of Santa Catarina (UFSC), PO Box 476, 88040-900 Florianópolis (SC), Brazil

${ }^{2}$ Graduate Program in Chemical Engineering (POSENQ), Department of Chemical Engineering (EQA), Federal University of Santa Catarina (UFSC), PO Box 476, 88040-900 Florianópolis (SC), Brazil

${ }^{3}$ Department of Materials and Ceramic Engineering / CICECO- Aveiro Institute of Materials, University of Aveiro, Campus Universitário de Santiago, 3810-193 Aveiro, Portugal

${ }^{4}$ Graduate Program in Materials Science and Engineering (PPGCEM), University of Southernmost Santa Catarina (UNESC), Brazil

*Corresponging author: lisandrosimao@gmail.com

(Received July 2017; accepted April 2018)

Key words: waste recycle, clinker, mortar

\begin{abstract}
Waste generation is increasing in many industries. Therefore, effective measures are required to secure an environmentally sustainable and economically viable waste destination. Co-processing in clinker kilns at high temperatures and incorporation into cement matrices may stabilize many types of industrial waste. This paper presents the results of a study that characterized pulp and paper mill waste and their recycling in clinker production. Chemical characterization and estimation of the hazardous potential of lime mud, biomass ash, and wastewater treatment plant (WWTP) sludge were performed in accordance with brazilian standard (NBR) 10004:2004. Biomass ash and WWTP sludge were classified as non-hazardous (class II), while lime mud was classified as hazardous ( $\mathrm{pH}>12.5$, class I). These wastes were mixed (69 wt \% lime mud, $29 \mathrm{wt} \%$ biomass ash, and $2 \mathrm{wt} \% \mathrm{WWTP}$ sludge), and the resulting mixture was processed at $1455^{\circ} \mathrm{C}$ to generate 'Ecoclinker'. The clinker was characterized, milled, and mixed with calcium sulphate for use as an 'Ecocement'. Mortars were obtained and cured for periods of seven and twenty-eight days. The hardened product exhibited a mechanical strength of $\sim 20 \mathrm{MPa}$. The leaching and $\mathrm{pH}$ tests indicated that these parameters were within the permitted limits, confirming that this waste-based cement was non-hazardous.
\end{abstract}

Palabras clave: reciclaje de residuos, clínker, mortero

\section{RESUMEN}

La generación de residuos sólidos está aumentando en muchos sectores industriales; por lo tanto, se requieren medidas efectivas para garantizar un descarte de residuos que sea ambientalmente adecuado y económicamente viable. El coprocesamiento en hornos de producción de clínker a altas temperaturas, así como la incorporación en 
matrices de cemento, son estrategias utilizadas para estabilizar muchos tipos de residuos industriales. En este estudio se analizan los resultados de un estudio acerca de la caracterización de residuos de papel y celulosa y su reciclaje en la producción de clínker. La caracterización química y la estimación del potencial peligroso de lodo de carbonato, la ceniza de biomasa y el lodo de la estación depuradora de aguas residuales (EDAR) se realizaron de acuerdo con la norma NBR 10004: 2004. La ceniza de biomasa y los lodos de la EDAR se clasificaron como no peligrosos (clase II), mientras que el lodo de carbonato se clasificó como peligroso $(\mathrm{pH}>12.5$, clase I). Una mezcla de estos residuos ( $69 \%$ en peso de lodo de carbonato, $29 \%$ en peso de ceniza de biomasa y $2 \%$ en peso de lodo de EDAR) fue procesada a $1455^{\circ} \mathrm{C}$ para generar el denominado Ecoclínker. El clínker fue caracterizado, molido y mezclado con sulfato de calcio para ser utilizado como Ecocement. Los morteros fueron obtenidos y curados por períodos de 7 y 28 días. El producto endurecido mostró una resistencia mecánica de $\sim 20 \mathrm{MPa}$. Las pruebas de lixiviación y $\mathrm{pH}$ estuvieron dentro de los límites permitidos, lo que confirma el carácter no peligroso del cemento a base de residuos.

\section{INTRODUCTION}

The appropriate management of waste materials and the reduction of environmental loads are a critical challenge for modern society to ensure that the pillars of sustainability are met.

Generally, most of these waste materials are disposed in municipal or industrial landfill. However, the inappropriate planning and operation of these landfills may cause ground and surface water contamination by the leakage of toxic compounds. In addition, soil contamination and a repulsive odour may be generated (Saikia et al. 2007). This practice does not recover the material/energy content of the waste, nor does it contribute to the development of a sustainable economy.

Many alternative technologies have been investigated to reduce the hazard potential of certain waste streams. Stabilisation in a solid state is one of the most common processes for encapsulating toxic species in an inert matrix (such as a cement-based matrix) (Miranda et al. 2011, Modolo et al. 2011, Pinheiro et al. 2013, Siqueira and Holanda 2013). Ceramisation or vitrification may also be implemented, but they require more energy and monetary investment unless a valuable product is obtained that can mitigate these expenses (Mangialardi 2001, Park and Heo 2002, Buruberri et al. 2015).

Co-processing in clinker kilns is an efficient thermal stabilisation technique owing to the high temperature used and long residence time of gases (Saikia et al. 2007, Wang et al. 2010). These characteristics provide co-processing with more advantages than traditional incinerators as lower atmospheric emissions are produced and the environmental impacts can be minimized.
Paper pulp production generates a variety of waste types, including ash from biomass combustion, green liquor dregs, slake grits, lime mud, and WWTP sludge (Wirojanagud et al. 2004, Monte et al. 2009). Some of these wastes have been combined to produce clinker (Buruberri et al. 2015) as they may contain high amounts of $\mathrm{CaO}, \mathrm{Al}_{2} \mathrm{O}_{3}$, and $\mathrm{SiO}_{2}$. The eventual organic content may also be viewed an alternative source of energy, which commonly occurs with refuse-derived fuels (Martins et al. 2007, Sun et al. 2013, Qin et al. 2015).

In general, these wastes are non-hazardous (García et al. 2008, Ribeiro 2010, Siqueira and Holanda 2013) excluding lime mud, dregs, and grits due to their high alkalinity (Nurmesniemi et al. 2005, Almeida et al. 2007, Cabral et al. 2008, He et al. 2009, Pérez-López et al. 2010, Mäkitalo 2012, Branco et al. 2013, Jia et al. 2013, Zhang et al. 2013).

Risks associated with those materials may arise when alkaline leakage occurs and the $\mathrm{pH}$ levels, chemical oxygen demand (COD), and sulfate concentration of contaminated water increase (Mayes and Younger 2006, Mayes et al. 2008, Gomes et al. 2016). These changes in water properties may affect light penetration and cause the destruction of aquatic ecosystems (Andrews et al. 1997, Rogerson et al. 2008, Hull et al. 2014, Gomes et al. 2016). An alkaline pH (8.5 to 10) in aquatic environments causes severe physiological disorders in most fish species as it inhibits ammonia excretion and causes it to accumulate in their tissues, resulting in with toxicity and eventually death (Saha et al. 2002, Gomes et al. 2016).

Some studies have tried to employ the high alkalinity of these materials in useful applications. For example, Wirojanagud et al. (2004) and Sthiannopkao and Sreesai (2009) treated acidic 
metallurgical effluents with lime mud, and achieved $\mathrm{Zn}$ and $\mathrm{Hg}$ removal efficiencies higher than $99 \%$, and $\mathrm{Cu}, \mathrm{Pb}$, and $\mathrm{Cd}$ removal efficiencies beyond $90 \%$. Perez-Lopes et al. (2010) used this material to treat acid mine drainage and achieved similar removal efficiencies.

In this study, balanced combinations of lime mud, biomass ash, and WWTP sludge were formulated and thermally treated to generate clinker, and the cement produced with that clinker was then used in mortars. After curing, the products were characterized in terms of their physical and mechanical properties and $\mathrm{pH}$ levels. Leaching tests were also conducted.

\section{EXPERIMENTAL}

\section{Materials}

The following materials were used in this work:

(i) Biomass ash, WWTP sludge (mix of primary and secondary sludge coming industry), and lime mud, to produce Ecoclinker;

(ii) Gypsum $\left(\mathrm{D}_{50}=0.03 \mathrm{~mm}\right)$ to produce Ecocement;

(iii) Standard sand (size $1.2 \mathrm{~mm}$ - batch 41/2014, 0.6 $\mathrm{mm}$ - batch 10/2015, $0.3 \mathrm{~mm}$ - 14/2015 batch, and $0.15 \mathrm{~mm}-14 / 2015 \mathrm{batch}$ ) for formulating the mortars as specified by NBR 7215: 1997 (IPT 2016).

Eucalyptus and pine trees provided biomass for obtaining cellulose through the Kraft process. Ashes were from fluidized bed burning using the same biomass.

\section{Waste characterization}

The waste was characterized by determining its moisture content, density (gravimetric method), amount of free liquids according to NBR 12988:1993 (ABNT 1993), and oils and grease (gravimetric method with extraction using an ethyl ether). The chemical composition was determined by wavelength dispersive X-ray fluorescence spectrometry (WDXRF Axios Max Panalytical), and the loss on ignition (LOI) was estimated at $1000^{\circ} \mathrm{C}$.

The hazardous characteristics of the waste and obtained products were estimated by NBR 10004:2004 (ABNT 2004a). The wastes are classified as either hazardous (class I) or non-hazardous (class II). Non-hazardous wastes are further divided into noninert (IIA) or inert (IIB). The tests reported in NBR 10004:2004 (ABNT 2004a) are all based on USEPASW 846 (USEPA 2016), and were conducted after the sample pieces were ground and sieved below $9.5 \mathrm{~mm}$.

The corrosiveness, reactivity, and toxicity were evaluated to determine whether the waste would be hazardous (class I). The waste is classified as corrosive when the $\mathrm{pH}$ of the sample mixed with water in a 1:1 ratio is below 2 or above 12.5. The waste is designated as reactive when the concentrations of the $\mathrm{CN}^{-}$or $\mathrm{S}^{2-}$ ions exceed $250 \mathrm{mg}$ of $\mathrm{HCN}$ and $500 \mathrm{mg}$ of $\mathrm{H}_{2} \mathrm{~S}$ released per $\mathrm{kg}$ of waste, respectively. The cyanide test was conducted by colourimetry and ultraviolet-visible (UV/VIS) spectrophotometry with chloramine $\mathrm{T} / \mathrm{b}$ arbituric acid. The sulfide determination was performed through a preliminary distillation, and the distillate was then collected in a zinc acetate solution and titrated with sodium thiosulphate in the presence of a starch indicator.

The toxicity was determined by leaching, as described in NBR 10005:2004 (ABNT 2004b). Extraction solution 1 was used for analyzing the biomass ashes and WWTP sludge, while extraction solution 2 was used for lime mud. Extraction solution 1 contained $5.7 \mathrm{~mL}$ of glacial acetic acid, distilled water, and $64.3 \mathrm{~mL}$ of $\mathrm{NaOH} 1.0 \mathrm{~N}$, while extraction solution 2 contained $5.7 \mathrm{~mL}$ of glacial acetic acid and distilled water. The water was added to make up the solution volume to $1 \mathrm{~L}$.

To determine if the waste is non-inert (class IIA) or inert (class IIB), a solubility test was performed according to NBR 10006:2004 (ABNT 2004c). In this test, the sample was dried and distilled water was added ( $1000 \mathrm{~mL}$ of water per $250 \mathrm{~g}$ of sample). After 7 days, the extracts were then filtered through a $0.45-\mu \mathrm{m}$ pore size filter.

The leached and solubilized extracts were analyzed by plasma-optical emission spectrometry-ICP (Agilent, 720-OES) and the results were compared to the limits stated in the respective standards.

\section{Waste recycling}

The wastes were used without undergoing any treatment and homogenized in 2-mm (9 mesh) and 1 -mm (16 mesh) sieves. The raw mixture consisted of 69 wt \% lime mud, 29 wt \% biomass ash, and 2 wt \% WWTP sludge. These values were selected based on preliminary studies (Simão et al. 2017). The waste was thermally treated in a furnace (Fortelab model $\mathrm{ME} 1700 / \mathrm{V} / \mathrm{Eg}$ ) at $1000{ }^{\circ} \mathrm{C}$ for $120 \mathrm{~min}$ to promote decarbonation, and then at $1455{ }^{\circ} \mathrm{C}$ for a further 90 min to produce Ecoclinker, with heating rates of 5 and $10^{\circ} \mathrm{C} / \mathrm{min}$, respectively. These conditions were determined based on the ternary diagram of $\mathrm{CaO}-\mathrm{SiO}_{2}-\mathrm{Al}_{2} \mathrm{O}_{3}$ and the work of Buruberri et al. (2015). 
The obtained Ecoclinker was chemically and mineralogically characterized by WDXRF and Xray powder diffraction $(X R D$, Shimadzu XRD-6000, Japan) with $\mathrm{CuK} \alpha$ radiation, $0.02^{\circ} 2 \theta$ step-scan, and $10 \mathrm{~s} / \mathrm{step}$ with phase quantification by Rietveld refinement, respectively.

The Ecoclinker was crushed in a ring mill after the gypsum was added ( $5 \mathrm{wt} \%$ ) to form the Ecocement, with particles passing through a $45-\mu \mathrm{m}$ filter (325 mesh sieve).

The cement potential as a binder according to NBR 5732:1991 (ABNT 1991) was validated through the formulation of mortar samples $(50 \mathrm{~mm}$ in diameter and $100 \mathrm{~mm}$ in height) containing one part of Ecocement and three parts of sand in weight. The water/cement ratio (w/c) was 0.75 based on the workability tests of mortar in its fresh state. This test was conducted on a table to determine the consistency index according to NBR 7215:1996 (ABNT 1996).

Specimens were cured at room temperature for $24 \mathrm{~h}$ and then immersed in lime-saturated water for 28 days. After 7 and 28 days of curing, the samples were mechanically tested by compression (EMIC DL10000 machine) according to NBR 5739:2007 (ABNT 2007).

Broken pieces of the specimens that were cured for seven days were ground $(<9.5 \mathrm{~mm})$ to test the $\mathrm{pH}$, leaching according to NBR 10005:2004 (ABNT 2004b), and solubility based on NBR 10006:2004 (ABNT 2004c).

\section{RESULTS AND DISCUSSION}

\section{Waste characterization}

The WWTP sludge has a high moisture level ( $\sim 87 \mathrm{wt} \%$ ), therefore, only $2 \mathrm{wt} \%$ of this material was used in the formulation of Ecoclinker. A high moisture content in the formulation can generate problems in processing. The moisture values of the biomass ash and lime mud were $\sim 23$ and $\sim 26 \mathrm{wt} \%$, respectively. Free liquids were not identified in the waste, and the densities of the biomass ash, lime mud, and WWTP sludge were $0.36,0.74$, and $0.81 \mathrm{~g} / \mathrm{mL}$, respectively (Table I).

The biomass ashes exhibited a high concentration of silica (49.60 wt \%), in addition to other important oxides required for the formulation of clinker, such as $\mathrm{Al}_{2} \mathrm{O}_{3}$ (9.94 wt \%), $\mathrm{Fe}_{2} \mathrm{O}_{3}$ (4.07 wt \%), and $\mathrm{CaO}$ (2.10 $\mathrm{wt} \%$ ). WWTP sludge is primarily composed of organic matter, the decomposition of which caused the high LOI (74.80 wt \%). Lime mud contains $53.60 \mathrm{wt} \%$ $\mathrm{CaO}$, confirming that is a rich source of calcite. The calcite had a LOI of $42.20 \mathrm{wt} \%$ (Table II). The CaO$\mathrm{SiO}_{2}-\mathrm{Al}_{2} \mathrm{O}_{3}$ ternary diagram presented in figure 1 shows the position of the waste, and provides the targeted region of Portland clinker.

The lime mud waste was classified as hazardous (class I) due to its corrosive nature. The $\mathrm{pH}$ (12.67) of the lime $\mathrm{mud} / \mathrm{water}$ mixture $(1: 1 \mathrm{w} / \mathrm{w})$ exceeded the limit set by the NBR 10004:2004 standard for nonhazardous materials (2.1 to 12.5) (Table III). The lime mud was also characterized as nonreactive (Table III)

TABLE I. PHYSIO-CHEMICAL CHARACTERISTICS OF THE STUDIED WASTE

\begin{tabular}{llll}
\hline Parameters & Biomass ash & Lime mud \\
\hline & & & \\
& & & \\
& & & \\
Aspect & Solid (powder) & Solid (sludge) & Solid (powder) \\
Colour & Black & Dark brown & Green \\
Moisture $(\mathrm{wt} \%)$ & 22.60 & 87.10 & 25.60 \\
Free liquids & Absent & Absent & Absent \\
Density $(\mathrm{g} / \mathrm{mL})$ & 0.36 & 0.81 & 0.74 \\
\hline
\end{tabular}

${ }^{\mathrm{a}}$ WWTP: Waste water treatment plant 
TABLE II. CHEMICAL COMPOSITIONS OF THE SAMPLES

\begin{tabular}{lcccr}
\hline Oxide $(w t ~ \%)$ & Lime mud & Biomass ash & ${ }^{a}$ WWTP sludge & Ecoclinker \\
\hline $\mathrm{Al}_{2} \mathrm{O}_{3}$ & 0.22 & 9.94 & 13.20 & 6.77 \\
$\mathrm{CaO}$ & 53.60 & 2.10 & 2.14 & 60.30 \\
$\mathrm{Fe}_{2} \mathrm{O}_{3}$ & 0.16 & 4.07 & 0.75 & 1.21 \\
$\mathrm{~K}_{2} \mathrm{O}$ & $<0.05$ & 3.14 & 0.30 & 0.44 \\
$\mathrm{MgO}$ & 0.91 & 1.25 & 0.32 & 1.31 \\
$\mathrm{MnO}$ & 0.10 & 0.24 & 0.29 & 0.20 \\
$\mathrm{Na}_{2} \mathrm{O}$ & 1.06 & 0.33 & 0.67 & 1.14 \\
$\mathrm{P}_{2} \mathrm{O}_{5}$ & 0.65 & 0.65 & 1.83 & 0.98 \\
$\mathrm{SiO}_{2}$ & 1.06 & 49.60 & 5.24 & 22.70 \\
$\mathrm{TiO}_{2}$ & $<0.05$ & 0.95 & 0.07 & 0.23 \\
$\mathrm{BaO}_{\mathrm{Co}} \mathrm{O}_{3}$ & - & $<0.10$ & $<0.10$ & 0.09 \\
$\mathrm{Cr}_{2} \mathrm{O}_{3}$ & - & $<0.10$ & $<0.10$ & 0.10 \\
$\mathrm{PbO}$ & - & 0.08 & $<0.10$ & 0.10 \\
$\mathrm{SrO}_{\mathrm{ZrO}}+\mathrm{HfO}_{2}$ & - & $<0.10$ & $<0.1$ & 0.10 \\
$\mathrm{LOI}$ & - & $<0.10$ & 0.18 & 0.16 \\
\hline
\end{tabular}

${ }^{\mathrm{a}} \mathrm{WWTP}=$ Waste water treatment plant, ${ }^{\mathrm{b}} \mathrm{LOI}=$ Loss on ignition

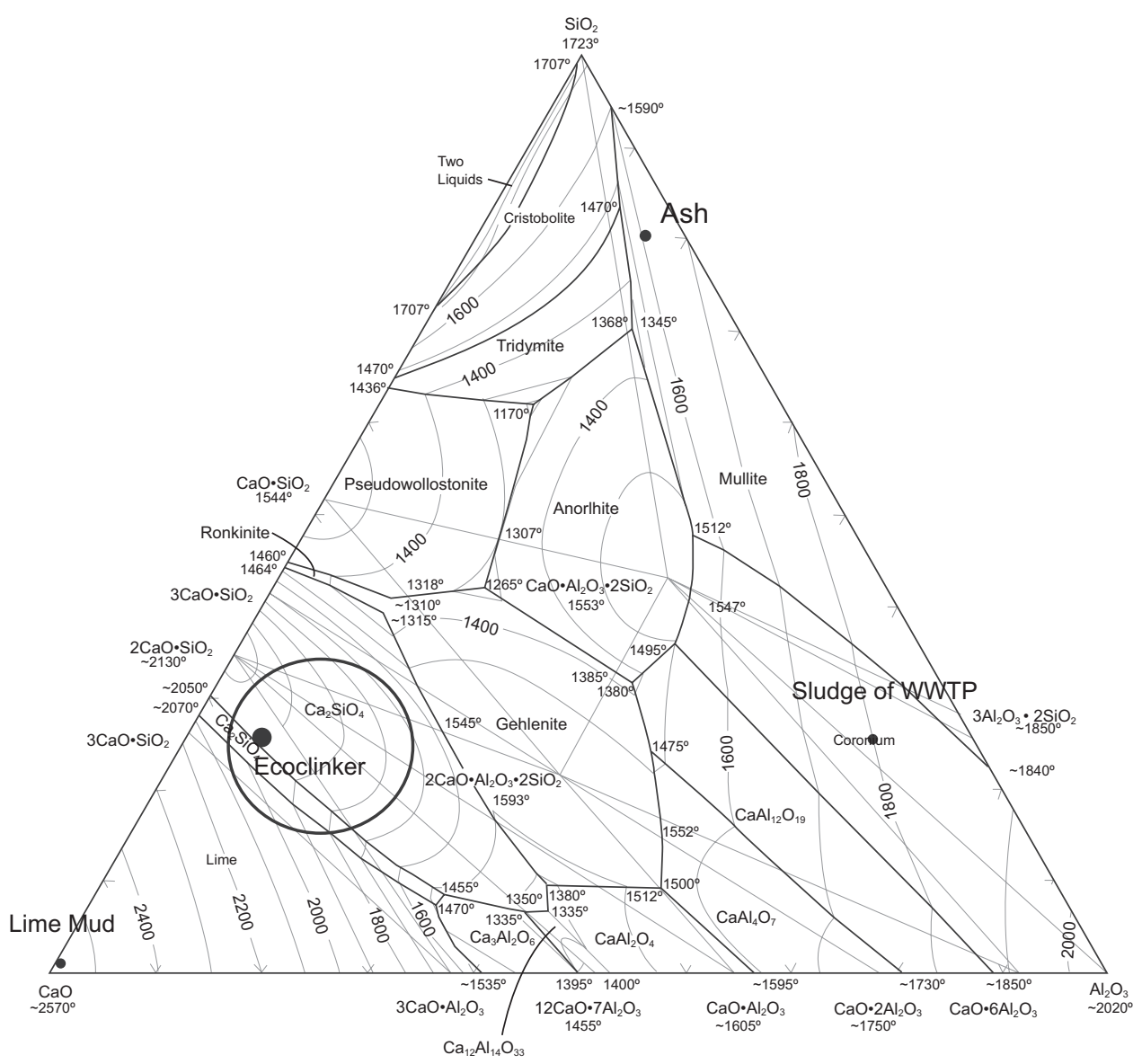

Fig. 1. Location of waste and Ecoclinker in the $\mathrm{CaO}-\mathrm{SiO}_{2}-\mathrm{Al}_{2} \mathrm{O}_{3}$ ternary diagram with the Portlandtype clinker compositional region. (WWTP: Waste water treatment plant) 
TABLE III. CORROSIVENESS AND REACTIVITY OF THE STUDIED WASTES

\begin{tabular}{lcccc}
\hline Parameters & ${ }^{\mathrm{a}}$ Recommended Value & ${ }^{\mathrm{b}}$ WWTP sludge & Lime mud & Biomass ash \\
\hline $\begin{array}{l}\text { Corrosiveness } \\
\text { pH in water }(1: 1)\end{array}$ & $2.00-12.40$ & 7.44 & 12.67 & 9.38 \\
\hline Reactivity & & & & \\
$\mathrm{HCN}(\mathrm{mg} / \mathrm{kg})$ & 250.00 & $<0.05$ & $<0.05$ & $<0.05$ \\
$\mathrm{H}_{2} \mathrm{~S}(\mathrm{mg} / \mathrm{kg})$ & 500.00 & $<40.00$ & Not Evaluated & $<40.00$ \\
\hline
\end{tabular}

${ }^{\mathrm{a}}$ Based on NBR 10004:2004, ${ }^{\mathrm{b}}$ WWTP $=$ Waste water treatment plant

and nontoxic, as all parameters evaluated in the leaching test presented values lower than those specified by the NBR 10004:2004 guideline (Table IV).

Biomass ash and WWTP sludge were also classified as noncorrosive and nonreactive as their $\mathrm{pH}$ values, as well as their cyanide and sulphite concentrations, were within the limits set by NBR 10004:2004 (Table III). These two wastes were also classified as nontoxic in the leaching test (Table IV).

The solubility test shows that only the aluminium concentration was above the permitted value of 0.2 $\mathrm{mg} / \mathrm{L}$ for biomass ashes $(0.6 \mathrm{mg} / \mathrm{L})$, thus, it was characterized as non-hazardous - class IIA - noninert. The WWTP sludge was also classified as IIA - non-inert, as the manganese and sodium concentra- tions exceeded the limits of 0.1 and $200 \mathrm{mg} / \mathrm{L}$ in the solubility test, respectively, which presented values of $0.19 \mathrm{mg} / \mathrm{L}$ for manganese and $284.07 \mathrm{mg} / \mathrm{L}$ for sodium (Table V).

\section{Waste recycling}

The chemical composition of the obtained Ecoclinker agreed well with the literature (Mehta and Monteiro 2005, Buruberri et al. 2015, Simão et al. 2017) (Table II and Fig. 1), with calcium (60.33 wt \%), silicon (22.70 wt \%) and aluminium (6.77 wt \%) oxides dominating the material's composition.

The diffractogram (Fig. 2) shows the peaks of the main crystalline phases found in the clinkers, such as the calcium silicates alite (C3S, JCPDS: 49-

TABLE IV. LEACHING RESULTS OF THE STUDIED WASTE

\begin{tabular}{lcccc}
\hline Parameters (mg/L) & ${ }^{\mathrm{a}}$ Recommended value & ${ }^{\mathrm{b}}$ WWTP sludge & Lime mud & Biomass ash \\
\hline Arsenic & 1.00 & $<0.01$ & $<0.01$ & $<0.01$ \\
Barium & 70.00 & 0.35 & 0.20 & 0.40 \\
Cadmium & 0.50 & $<0.005$ & $<0.005$ & $<0.005$ \\
Lead & 1.00 & $<0.01$ & $<0.01$ & $<0.01$ \\
Total chrome & 5.00 & $<0.01$ & $<0.01$ & $<0.01$ \\
Fluoride & 150.00 & $<0.10$ & 1.10 & $<0.10$ \\
Mercury & 0.10 & $<0.001$ & $<0.001$ & $<0.001$ \\
Silver & 5.00 & $<0.01$ & $<0.01$ & $<0.01$ \\
Selenium & 1.00 & $<0.01$ & $<0.01$ & $<0.01$ \\
Benzene & 0.50 & $<0.002$ & & $<0.002$ \\
Chlorobenzene & 100.00 & $<0.002$ & & $<0.002$ \\
Chloroform & 6.00 & $<0.002$ & & $<0.002$ \\
1,4 Dichlorobenzene & 7.50 & $<0.002$ & & $<0.002$ \\
1,2 Dichloroethane & 1.00 & $<0.002$ & & $<0.002$ \\
1,1 Dichloroethylene & 3.00 & $<0.002$ & & $<0.002$ \\
Hexachlorobutadiene & 0.50 & $<0.002$ & & $<0.002$ \\
Carbon tetrachloride & 0.20 & $<0.002$ & & $<0.002$ \\
Tetrachloroethylene & 4.00 & $<0.002$ & & $<0.002$ \\
Trichloroethene & 7.00 & $<0.002$ & & \\
\hline
\end{tabular}

Blank spaces $=$ not evaluated, ${ }^{\mathrm{a}}$ Based on Brazilian standard NBR 10004:2004, ${ }^{\mathrm{b}} \mathrm{WWTP}=$ Waste water treatment plant 
TABLE V. SOLUBILIZATION RESULTS OF THE STUDIED WASTE

\begin{tabular}{lccc}
\hline $\begin{array}{l}\text { Parameters } \\
(\mathrm{mg} / \mathrm{L})\end{array}$ & $\begin{array}{c}\text { a Recommended } \\
\text { value }\end{array}$ & $\begin{array}{c}\text { b WWTP } \\
\text { sludge }\end{array}$ & $\begin{array}{c}\text { Biomass } \\
\text { ash }\end{array}$ \\
\hline Aluminium & 0.20 & 0.20 & 0.60 \\
Arsenic & 0.01 & $<0.01$ & $<0.01$ \\
Barium & 0.70 & $<0.01$ & $<0.01$ \\
Cadmium & 0.005 & $<0.005$ & $<0.005$ \\
Lead & 0.01 & $<0.01$ & $<0.01$ \\
Chloride & 250.00 & 9.00 & $<5.00$ \\
Copper & 2.00 & $<0.005$ & $<0.005$ \\
Total chromium & 0.05 & $<0.01$ & $<0.01$ \\
Total phenols & 0.01 & $<0.01$ & $<0.01$ \\
Iron & 0.30 & $<0.10$ & $<0.10$ \\
Fluoride & 1.50 & $<0.10$ & $<0.10$ \\
Manganese & 0.10 & 0.19 & $<0.01$ \\
Mercury & 0.001 & $<0.001$ & $<0.001$ \\
Nitrate (as N) & 10.0 & $<0.1$ & $<0.1$ \\
Silver & 0.05 & $<0.01$ & $<0.01$ \\
Selenium & 0.01 & $<0.01$ & $<0.01$ \\
Sodium & 200.00 & 284.07 & 25.31 \\
Sulfate (as SO 4$)$ & 250.00 & 10.00 & 6.00 \\
Surfactants & 0.50 & $<0.10$ & $<0.10$ \\
Zinc & 5.00 & $<0.01$ & $<0.01$ \\
\hline
\end{tabular}

${ }^{\mathrm{a}}$ Based on Brazilian standard NBR 10004:2004, ${ }^{\mathrm{b}}$ WWTP $=$ Waste water treatment plant

0442) and belite (C2S, JCPDS: 33-0302), as well as tricalcium aluminate (C3A, JCPDS: 38-1429) and ferric tetracalcium (C4AF, JCPDS: 30-0226). The Rietveld quantification showed that alite was the predominant phase (46 wt \%), which is typical of Portland cement.

In its fresh state, the slump flow of the Ecocementbased mortar was $78.5 \%$ using a w/c ratio of 0.75 . In their hardened state, the cured mortars presented satisfactory mechanical strength in comparison to the values found in the literature (Raupp-Pereira et al. 2008, Buruberri et al. 2015) (Fig. 2). They are perfectly applicable as coating mortars, which require less mechanical strength (1-2 MPa). It is also worth noting that the mechanical strength values are very close to the minimum limit (25 MPa) set by NBR 5732:1991 (ABNT 1991) for the class of $25 \mathrm{MPa}$ (Fig. 3). This standard specifies the mechanical strength values for common Portland cement in Brazil.

The leaching test presented no evidence of hazard (Table VI), therefore, the product could be classified as non-toxic and non-hazardous. Its $\mathrm{pH}(11.45)$ is also below the limit of corrosiveness.

The results of the solubility test of the mortar (Table VII) indicated that the total chromium and

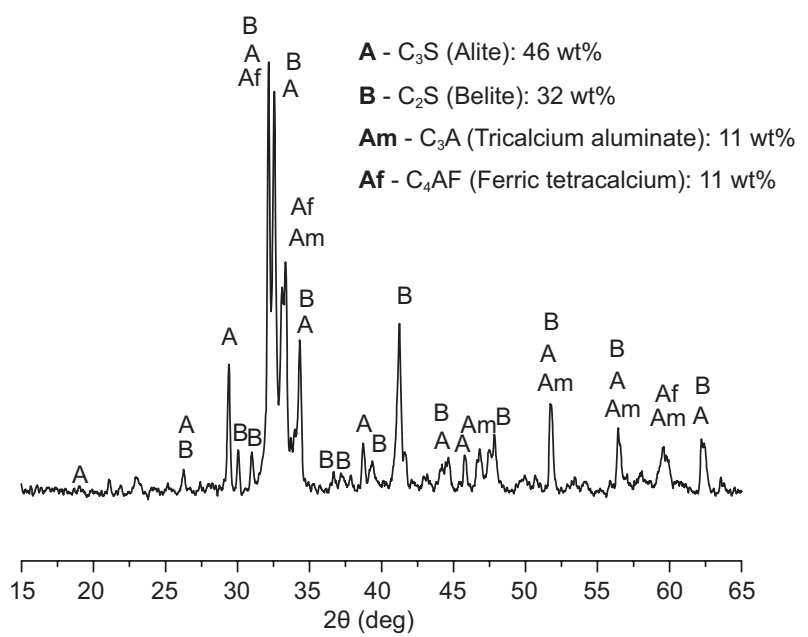

Fig. 2. X-ray powder diffraction (XRD) patterns of the Ecoclinker

phenol values exceeded the limits established by NBR 10004:2004, therefore, the product was characterized as non-inert.

The results obtained for the material formulated entirely from waste indicate the feasibility of these materials to be explored by the cement industry as an 


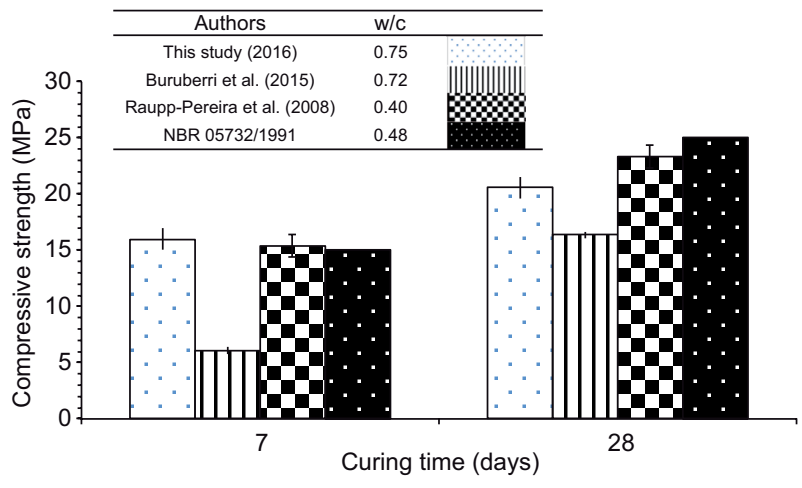

Fig. 3. Compressive strength (MPa) of the mortars and a comparison with literature/standard results

TABLE VI. PHYSIO-CHEMICAL CHARACTERISTICS OF THE MORTARS CURED FOR SEVEN DAYS

\begin{tabular}{lcc}
\hline Parameters & ${ }^{a}$ Recommended value & Mortar \\
\hline $\mathrm{pH}$ & $2.0-12.40$ & 11.45 \\
Density $(\mathrm{g} / \mathrm{mL})$ & - & 0.67 \\
Leached $(\mathrm{g} / \mathrm{mL})$ & & \\
Arsenic & 1.00 & $<0.01$ \\
Barium & 70.00 & 0.38 \\
Cadmium & 0.50 & $<0.005$ \\
Lead & 1.00 & $<0.01$ \\
Total chrome & 5.00 & 1.25 \\
Fluoride & 150.00 & 0.23 \\
Silver & 5.00 & $<0.01$ \\
Selenium & 1.00 & $<0.01$ \\
\hline
\end{tabular}

${ }^{a}$ Based on Brazilian standard NBR 10004:2004

alternative mineral source to produce clinkers, and of the application of these products as hydraulic binders.

\section{CONCLUSIONS}

Chemical characterization of lime mud, biomass ash, and WWTP sludge revealed their potential to be used as raw materials in cement (high $\mathrm{CaO}, \mathrm{SiO}_{2}$, $\mathrm{Al}_{2} \mathrm{O}_{3}$, and organic matter content). The conducted tests classified the waste as non-hazardous (class II), with the exception of lime mud, which had a $\mathrm{pH}>12.5$ (12.67) and was classified as corrosive (class I). These wastes were stabilized by clinkering which improved the functionality of the resultant Ecoclinker. Mortars that were cured for 28 days exhibited a mechanical resistance of $\sim 20 \mathrm{MPa}$. The hazard test demonstrated that the $\mathrm{pH}$ of the mortars was $<12.5$, and the leaching test indicated that the concentrations of all the compounds were within the
TABLE VII. RESULTS OF MORTAR SOLUBILIZATION TESTS

\begin{tabular}{|c|c|c|}
\hline Parameters (mg/L) & ${ }^{\mathrm{a}}$ Recommended value & Mortar \\
\hline Aluminium & 0.20 & 0.20 \\
\hline Arsenic & 0.01 & $<0.01$ \\
\hline Barium & 0.70 & 0.57 \\
\hline Cadmium & 0.005 & $<0.005$ \\
\hline Lead & 0.01 & $<0.01$ \\
\hline Chloride & 250.0 & 9.00 \\
\hline Copper & 2.00 & $<0.01$ \\
\hline Total chrome & 0.05 & 0.39 \\
\hline Total phenols & 0.01 & 0.03 \\
\hline Iron & 0.30 & $<0.02$ \\
\hline Fluoride & 1.50 & $<1.00$ \\
\hline Manganese & 0.10 & $<0.01$ \\
\hline Mercury & 0.001 & $<0.001$ \\
\hline Nitrate (as N) & 10.00 & $<1.00$ \\
\hline Silver & 0.05 & $<0.01$ \\
\hline Selenium & 0.01 & $<0.01$ \\
\hline Sodium & 200.00 & 125.00 \\
\hline Sulfate (as $\mathrm{SO}_{4}$ ) & 250.00 & $<100.00$ \\
\hline Surfactants & 0.50 & $<0.10$ \\
\hline Zinc & 5.00 & $<0.01$ \\
\hline
\end{tabular}

${ }^{a}$ Based on Brazilian standard NBR 10004:2004

limits set by NBR 10004:2004. The stabilisation of lime mud, biomass ashes, and WWTP sludge waste in cement matrixes and clinkers which were formulated exclusively from these materials demonstrates the potential of this method as an alternative to the current destination and treatment methods for pulp and paper mill waste.

\section{ACKNOWLEDGMENTS}

The authors are very grateful to Coordenação de Aperfeiçoamento de Pessoal de Nível Superior (CAPES/Brazil) and Conselho Nacional de Desenvolvimento Científico e Tecnológico (CNPq/Brazil) for funding this work.

\section{REFERENCES}

ABNT (2007). NBR 5739. Concreto, Ensaios de compressão de corpos cilindricos, Associação Brasileira de Normas Técnicas. Standart. Rio de Janeiro, RJ, Brazil, 9 pp.

ABNT (2004a). NBR 10004. Resíduos sólidos, Classificação, Associação Brasileira de Normas Técnicas. Standart. Rio de Janeiro, RJ, Brazil, 71 pp. 
ABNT (2004b). NBR 10005. Procedimento para obtenção de lixiviado de resíduos sólidos, Associação Brasileira de Normas Técnicas. Standart. Rio de Janeiro, RJ, Brazil, 16 pp.

ABNT (2004c). NBR 10006. Procedimento para obtenção de extrato solubilizado de resíduos sólidos, Associação Brasileira de Normas Técnicas. Manual. Rio de Janeiro, RJ, Brazil, 3 pp.

ABNT (1996). NBR 7215. Cimento Portland, Determinação da resistência à compressão, Associação Brasileira de Normas Técnicas. Standart. Rio de Janeiro, RJ, Brazil, 8 pp.

ABNT (1993). NBR 12988. Líquidos livres, Verificação em amostra de resíduos, Método de ensaio. Associação Brasileira de Normas Técnicas. Manual. Rio de Janeiro, RJ, Brazil, 2 pp.

ABNT (1991). NBR 5732. Cimento Portland comum, Associação Brasileira de Normas Técnicas. Standart. Rio de Janeiro, RJ, Brazil, 5 pp.

Almeida H.C., Da Silveira, C.B., Ernani P.R., Campos M.L. and Almeida D. (2007). Composição química de um resíduo alcalino da indústria de papel e celulose (DREGS). Quim. Nova 30 (7), 1669-1672.

DOI: $10.1590 / \mathrm{S} 0100-40422007000700032$

Andrews J.E., Gare S.G. and Dennis P.F. (1997). Unusual isotopic phenomena in Welsh quarry water and carbonate crusts. Terra Nov. 9 (2), 67-70.

DOI: 10.1111/j.1365-3121.1997.tb00004.x

Branco S.B., Silveira C.B., Campos M.L., Gatiboni L.C. and Miquelluti D.J. (2013). Atributos químicos do solo e lixiviação de compostos fenólicos após adição de resíduo sólido alcalino. Rev. Bras. Eng. Agrícola e Ambient. 17 (5), 543-550.

DOI: $10.1590 /$ S1415-43662013000500012

Buruberri L.H., Seabra M.P. and Labrincha J. A. (2015). Preparation of clinker from paper pulp industry wastes. J. Hazard. Mater. 286, 252-260.

DOI: $10.1016 /$ j.jhazmat.2014.12.053

Cabral F., Ribeiro H.M., Hilário L., Machado L. and Vasconcelos E. (2008). Use of pulp mill inorganic wastes as alternative liming materials. Bioresour. Technol. 99 (17), 8294-8298.

DOI: 10.1016/j.biortech.2008.03.001

García R., Vigil de la Villa R., Vegas I., Frías M. and Sánchez de Rojas M.I. (2008). The pozzolanic properties of paper sludge waste. Constr. Build. Mater. 22 (7), 1484-1490.

DOI: 10.1016/j.conbuildmat.2007.03.033

Gomes H.I., Mayes W.M., Rogerson M., Stewart D.I. and Burke I.T. (2016). Alkaline residues and the environment: a review of impacts, management practices and opportunities. J. Clean. Prod. 112, 3571-3582.

DOI: 10.1016/j.jclepro.2015.09.111
He J., Lange C.R. and Dougherty M. (2009). Laboratory study using paper mill lime mud for agronomic benefit. Process Saf. Environ. Prot. 87 (6), 401-405. DOI: 10.1016/j.psep.2009.08.001

Hull S.L., Oty U.V. and Mayes W.M. (2014). Rapid recovery of benthic invertebrates downstream of hyperalkaline steel slag discharges. Hydrobiologia 736 (1), 83-97.

DOI: $10.1007 / \mathrm{s} 10750-014-1894-5$

IPT (2016). Areia Normal Brasileira. Instituto de Pesquisas Tecnológicas [online]. http://www.ipt.br/areianormal 21/04/2018.

Jia Y., Maurice C. and Öhlander B. (2013). Effect of the alkaline industrial residues fly ash, green liquor dregs, and lime mud on mine tailings oxidation when used as covering material. Environ. Earth Sci. 72 (2), 319-334. DOI: $10.1007 / \mathrm{s} 12665-013-2953-3$

Mäkitalo M. (2012). Green liquor dregs as sealing layer material to cover sulphidic mine waste deposits. Licentiate Dissertation. Luleå University of Technology. Luleå, Sweeden, $20 \mathrm{pp}$.

Mangialardi T. (2001). Sintering of MSW fly ash for reuse as a concrete aggregate. J. Hazard. Mater. 87 (1-3), 225-239. DOI: $10.1016 / \mathrm{S} 0304-3894(01) 00286-2$

Martins F.M., Martins J.M., Ferracin L.C. and da Cunha C.J. (2007). Mineral phases of green liquor dregs, slaker grits, lime mud and wood ash of a Kraft pulp and paper mill. J. Hazard. Mater. 147 (1-2), 610-617. DOI: $10.1016 /$ j.jhazmat.2007.01.057

Mayes W.M. and Younger P.L. (2006). Buffering of alkaline steel slag leachate across a natural wetland. Environ. Sci. Technol. 40 (4), 1237-1243. DOI: $10.1021 / \mathrm{es} 051304 \mathrm{u}$

Mayes W.M., Younger P.L. and Aumônier J. (2008). Hydrogeochemistry of alkaline steel slag leachates in the UK. Water. Air. Soil Pollut. 195 (1-4), 35-50. DOI: $10.1007 / \mathrm{s} 11270-008-9725-9$

Mehta P.K. and Monteiro P.J.M. (2005) Concrete: Microstructure, properties, and materials. 3rd ed. McGrawHill Professional. New York City, USA. 659 pp.

Miranda L. de A., Alvarenga R. de C.S.S., Pinto P.C.M.J., Junior E.D. de P., Carvalho C.A.B., Fassoni D.P. and Couto L.G. (2011). Avaliação do potencial do grits como material de construção na produção de tijolos de solo-cimento. Rev. Árvore 35 (6), 1335-1340. DOI: $10.1590 / \mathrm{S} 0100-67622011000700020$

Modolo R., Senff L., Ferreira V.M., Labrincha J.A. and Tarelho L.A. (2011). Use of lime-mud from pulp mill plant in cement-mortars. In: 1st International Conference of Wastes: Solutions, Treatments and Oportunities. Guimarães, Portugal.

Monte M.C., Fuente E., Blanco A. and Negro C. (2009). Waste management from pulp and paper production in 
the European Union. Waste Manag. 29 (1), 293-308. DOI: 10.1016/j.wasman.2008.02.002

Nurmesniemi H., Pöykiö R., Perämäki P. and Kuokkanen T. (2005). The use of a sequential leaching procedure for heavy metal fractionation in green liquor dregs from a causticizing process at a pulp mill. Chemosphere 61 (10), 1475-1484.

DOI: 10.1016/j.chemosphere.2005.04.114

Park Y.J. and Heo J. (2002). Vitrification of fly ash from municipal solid waste incinerator. J. Hazard. Mater. 91 (1-3), 83-93. DOI: 10.1016/S0304-3894(01)00362-4

Pérez-López R., Castillo J., Quispe D. and Nieto J.M. (2010). Neutralization of acid mine drainage using the final product from $\mathrm{CO}_{2}$ emissions capture with alkaline paper mill waste. J. Hazard. Mater. 177 (1-3), 762-72. DOI: 10.1016/j.jhazmat.2009.12.097

Pinheiro M.L., Alvarenga R. de C.S.S.A., Ribeiro B.C., Júnior P.R.S., Sarmet M.S. and Fassoni D.P. (2013). Avaliação experimental de blocos prensados de solocimento com adição de grits. Ambient. Construído 13 (2), 29-35. DOI: 10.1590/S1678-86212013000200004

Qin J., Cui C., Cui X., Hussain A., Yang C. and Yang S. (2015). Recycling of lime mud and fly ash for fabrication of anorthite ceramic at low sintering temperature. Ceram. Int. 41 (4), 5648-5655.

DOI: 10.1016/j.ceramint.2014.12.149

Raupp-Pereira F., Ball R.J., Rocha J., Labrincha J. A. and Allen G.C. (2008). New waste based clinkers: Belite and lime formulations. Cem. Concr. Res. 38 (4), 511521. DOI: $10.1016 /$ j.cemconres.2007.11.008

Ribeiro A.P. (2010). Avaliação do uso de resíduos sólidos inorgânicos da produção de celulose em materiais cerâmicos. Tese de doutorado. Escola Politécnica da Universidade de São Paulo. São Paulo, Brasil, 142 pp.

Rogerson M., Pedley H.M., Wadhawan J.D. and Middleton R. (2008). New insights into biological influence on the geochemistry of freshwater carbonate deposits. Geochim. Cosmochim. Acta 72 (20), 4976-4987. DOI: $10.1016 /$ j.gca.2008.06.030

Saha N., Kharbuli Z.Y., Bhattacharjee A., Goswami C. and Häussinger D. (2002). Effect of alkalinity ( $\mathrm{pH} \mathrm{10)}$ on ureogenesis in the air-breathing walking catfish, Clarias batrachus. Comp. Biochem. Physiol. Part A Mol. Integr. Physiol. 132 (2), 353-364. DOI: 10.1016/S1095-6433(02)00044-2
Saikia N., Kato S. and Kojima T. (2007). Production of cement clinkers from municipal solid waste incineration (MSWI) fly ash. Waste Manag. 27 (9), 1178-1189. DOI: 10.1016/j.wasman.2006.06.004

Simão L., Jiusti J., Lóh N.J., Hotza D., Raupp-Pereira F., Labrincha J.A. and Montedo O.R.K. (2017). Wastecontaining clinkers: Valorization of alternative mineral sources from pulp and paper mills. Process Saf. Environ. Prot. 109, 106-116.

DOI: $10.1016 /$ j.psep.2017.03.038

Siqueira F.B. and Holanda J.N.F. (2013). Reuse of grits waste for the production of soil-cement bricks. J. Environ. Manage. 131, 1-6. DOI: 10.1016/j.jenvman.2013.09.040

Sthiannopkao S. and Sreesai S. (2009). Utilization of pulp and paper industrial wastes to remove heavy metals from metal finishing wastewater. J. Environ. Manage. 90, 3283-3289. DOI: 10.1016/j.jenvman.2009.05.006

Sun R., Li Y., Liu C., Xie X. and Lu C. (2013). Utilization of lime mud from paper mill as $\mathrm{CO}_{2}$ sorbent in calcium looping process. Chem. Eng. J. 221, 124-132.

DOI: $10.1016 /$ j.cej.2013.01.068

USEPA (2016). SW 846. Hazardous Waste Test Methods. United States Environmental Protecion Agency. Manual. Washington, D.C., USA, 295 pp.

Wang L., Jin Y., Nie Y. and Li R. (2010). Recycling of municipal solid waste incineration fly ash for ordinary Portland cement production: A real-scale test. Resour. Conserv. Recycl. 54 (12), 1428-1435.

DOI: 10.1016/j.resconrec.2010.06.006

Wirojanagud W., Tantemsapya N. and Tantriratna P. (2004). Precipitation of heavy metals by lime mud waste of pulp and paper mill. Songklanakarin J. Sci. Technol. 26 (suppl 1), 45-53.

Zhang J., Wang Q. and Jiang J. (2013). Lime mud from paper-making process addition to food waste synergistically enhances hydrogen fermentation performance. Int. J. Hydrog. Energy 38 (6), 2738-2745.

DOI: 10.1016/j.ijhydene.2012.12.048 